\section{SELECTIVE FISCAL MEASURES AND THE DEFINITION OF THE RELEVANT REFERENCE FRAMEWORK IN THE LIGHT OF CASES C.I 06/09 P, COMMISSION V GIBRALTAR AND C.203/I 6 P, HEITKAMP BAUHOLDING V COMMISSION}

Hanna-Mari Immonen

DOI: https://doi.org/10.33344/vol13iss2pp64-75

Helsinki Law Review, 2/2019, pp. 64-75

(c) 2019 Pykälä ry, Mannerheimintie 3 B, 5th floor, 00100 Helsinki, Finland, and the author.

\section{$\mathbf{y}$}

TRTAISARVIOITU

KOLLEGIALT GRANSK
PEER-REVIIEWED
PWw.tsv.filtunnus

Keywords:

European Union law, internal market, State aid, selectivity

\section{ABSTRACT}

This article examines fiscal State aids and the selectivity condition. Assessing the selectivity is relatively complex in tax matters since it involves the analysis of the general tax system in which the regime under review applies. The focus of this article is on the selectivity analysis and the analysis of the general tax system i.e. the determination of the relevant reference framework. The definition of the relevant reference framework is still open to various interpretations despite the fact that the European Court of Justice has examined selectivity issues in several cases in the 2000s. The Gibraltar judgement has materially broadened the interpretation of the selectivity condition and the application of Article 107(1) TFEU. The Heitkamp BauHolding judgment confirms the interpretation adopted in the Gibraltar judgement, but also defines the scope of Article 107(1) TFEU in more detail. Yet the offset of the selectivity assessment i.e. the determination of the relevant reference system is still receptive to various interpretations.

1 The author is an LL.M. student at the University of Helsinki. This article is based on a case analysis written for a course in EU State aid law.

\section{INTRODUCTION}

In accordance with the usual allocation of competence in tax matters between the EU and the Member States, direct taxation falls within the competence of the Member States. However, Member States must exercise that competence consistently with EU law. ${ }^{2}$ It may be in a Member State's interest to attract foreign enterprises or investments by applying preferential tax treatment to a certain group of undertakings. Such measures may cause harmful tax competition between the Member States, but also distort the competition in the internal market. ${ }^{3} \mathrm{EU}$ tax law instruments aim to prevent harmful tax competition and tax evasion within the EU, while the EU State aid regulations tackle the competition concerns resulting from incompatible tax regimes.

To constitute prohibited State aid, a measure has to fulfil four cumulative conditions listed in Article 107(1) the Treaty on the Functioning of the European Union (TFEU) ${ }^{4}$. First, the aid has to be granted by a Member State or through State resources. Second, the measure has to confer a selective advantage to certain undertakings or the production of certain goods. Third, the measure must be liable to affect trade between Member States. Fourth, the measure must distort or threaten to distort competition in the internal market.

This analysis deals with the second condition i.e. the selectivity condition. It is interesting to notice that selectivity has not been under scrutiny in the old leading EU State aid cases, but today, selectivity is probably the most important issue when it comes to fiscal aids. ${ }^{\mathbf{5}}$ Assessing the selectivity condition is relatively complex in tax matters since it involves the analysis of the general tax system in which the regime under review applies. ${ }^{6}$ The focus of this article is on the analysis of the general tax system i.e. the determination of the relevant reference framework. This article discusses recent EU case law and the definition of the relevant reference framework regarding materially selective fiscal measure. The focus is on the analysis of two landmark judgements. This article does not analyse the justification but only discusses the problematics related to the first two stages of the three-stage analysis adopted by the European Court of Justice (ECJ).

2 See e.g. Judgement 29 March 2012, 3M Italia C-417/10, EU:C:2012:184, para 25 and Judgement 22 June 2006, Belgium and Forum 187 ASBL V. Commission Joined Cases C-182/03 and C-217/03, ECLI:EU:C:2006:416, para 81.

3 See also e . Helminen Marjaana, EU Tax Law - Direct Taxation. IBFD 2018 (Helminen 2018) p.35-42 on harmful tax competition.

4 Consolidated version of the Treaty on the Functioning of the European Union, OJ 2012 C 326

5 See e.g. José Luis Buendia Sierra, Finding Selectivity or the Art of Comparison. European State Aid Law Quarterly 2018 (Sierra 2018), p.85.

6 Faull, Jonathan and Nikpay, Ali, The EU Law of Competition. 3rd edn, Oxford: Oxford University Press 2014 (Faull \& Nikpay 2014), p.1946. 


\section{SELECTIVITY ASSESSMENT IN TAX MATTERS}

Article 107 TFEU generally prohibits State aid unless it is justified by reasons of general economic development. ${ }^{\mathbf{P}}$ Pursuant to Article 107(1) TFEU,

"save as otherwise provided in the Treaties, any aid granted by a Member State or through State resources in any form whatsoever which distorts or threatens to distort competition by favouring certain undertakings or the production of certain goods shall, in so far as it affects trade between Member States, be incompatible with the internal market".

The Article does not include the definition of 'State aid'. The ECJ has taken a broad view on the issue: the notion of aid includes not only positive advantages, but also a negative benefit which relieves the recipient of charges which would otherwise be borne by their budgets. ${ }^{8}$ An example of this kind of negative benefit is a national tax regime which gives economic benefit in the form of a smaller tax burden for a certain group of undertakings. That type of incompatible tax advantage may result from various measures, for example in its simplest form, from a tax exemption or a special tax deduction. ${ }^{9}$

Article 107(1) TFEU prohibits State aid 'favouring certain undertakings or the production of certain goods'. This means that only selective advantages, and not advantages resulting from a general measure applicable without distinction to all economic operators, fall within the concept of State aid. ${ }^{10}$ In the course of the time, the ECJ has adopted a broad notion of selectivity. As a general rule, in order to determine whether a measure is selective, it must be examined whether that measure constitutes an advantage for certain undertakings in comparison with others which are in a comparable legal or factual situation."

To clarify the notion of selectivity, it is useful to distinguish between material and regional selectivity. Regional selectivity usually concerns circumstances where a Member State applies

7 See exemptions listed in Articles 107(2) and 107(3) TFEU.

8 See e.g. Judgement 8 December 2011, France Télécom v Commission C-81/10 P, ECLI:EU:C:2011:811, para 16, Judgement 22 November 2001 Ferring C-53/OO ECLI:EU:C:2001:627, para 15, Judgment 17 June 1999 Piaggio C-295/97 ECLI:EU:C:1999:313, para 34 and Judgement 15 March 1994 Banco Exterior de España v Ayuntamiento de Valencia C-387/92 ECLI:EU:C:1994:100, para 13.

9 Commission Notice on the application of the State aid rules to measures relating to direct business taxation, OJ $1998 \mathrm{C} 384 / 3$, para 9.

10 Judgement 18 July 2013, P Oy C-6/12, EU:C:2013:525, para 18

11 Judgement 6 September 2006, Portugal v Commission C-88/O3 ECLI:EU:C:2006:511, para 54, Judgement 3 March 2005 Heiser C-172/03 ECLI:EU:C:2005:130, para 40, Judgement 29 April 2004 GIL Insurance and Others C-308/01 ECLI:EU:C:2004:252, para 68 and Judgement 8 November 2001 Adria-Wien Pipeline and Wietersdorfer \& Peggauer Zementwerke C-143/99 ECLI:EU:C:2001:598, para 41. derogative measures within a defined geographical area. ${ }^{\mathbf{1 2}}$ This article discusses the material selectivity which itself may be distinguished between de jure and de facto selectivity. De jure selectivity results directly from the legal criteria and de facto selectivity can be established in cases where, although the formal criteria for the application of the measure are formulated in general and objective terms, the structure of the measure is such that its effects significantly favour a particular group of undertakings. To emphasize the importance of the broad notion of selectivity it should be borne in mind that aid in the form of an aid programme may also concern a whole economic sector and still be covered by Article 107(1) TFEU. ${ }^{13}$

It can be stated that the selectivity condition raises fewer difficulties in the analysis of positive advantages than in the analysis of negative ones, such as tax aids. ${ }^{14}$ Schön has said that the most problematic level to apply EU State aid rules to is national tax legislation. ${ }^{15}$ Due to the tax sovereignty of Member States non-taxation issues or tax allowances regarding direct taxation as such are not an issue under EU law. Therefore, additional factors to identify incompatible State aids in the area of national tax legislation are needed. It should also be noted that the selectivity requirement differs depending on whether the measure in question is envisaged as an individual aid or a general scheme of aid. ${ }^{16}$ The latter is usually the case in tax measures. Therefore, special attention on the selectivity condition must be paid in fiscal matters.

The ECJ has adopted a three-stage analysis when assessing the selectivity condition. ${ }^{17}$ The analysis was first construed in the Adria-Wien Pipeline judgement. ${ }^{18}$ The basic idea is first to identify a relevant reference framework and then determine whether a given measure constitutes a derogation from that framework insofar as it differentiates between economic operators who, in light of the objectives intrinsic to the system, are in a comparable factual and legal situation. ${ }^{19}$ This approach requires the definition of a benchmark against which preferential treatment

12 An example of regional selectivity is the so-called Azores case, see Judgement 6 September 2006 , Portugalv Commission C-88/O3 ECLI:EU:C:2006:511.

3 Judgement 17 June 1999 Belgium v Commission C-75/97 ECLI:EU:C:1999:311, para 33.

14 Faull \& Nikpay (2014), p.1946.

5 Wolfgang Schön, Tax Legislation and the Notion of Fiscal Aid: A Review of 5 Years of European Jurisprudence. In: Richelle I., Schön W., Traversa E. (eds) State Aid Law and Business Taxation. MP Studies in Tax Law and Public Finance, vol 6. Springer, Berlin, Heidelberg 2016 (Schön 2016), p.5.

16 Judgement 4 June 2015, Commission v MOL C-15/14 P, EU:C:2015:362, para 60.

17 Bacon has pointed out that the three-stage analysis of selectivity has emerged for complex cases, particularly tax cases. See Bacon, Kelyn, European Union Law of State Aid. Oxford: Oxford University Press 2017 (Bacon 2017), p.70. See also the Commission Notice on the notion of State aid as referred to in Article 107(1) of the Treaty on the Functioning of the European Union, OJ 2016 C 262, para 128 regarding the three-stage analysis.

18 Judgement 8 November 2001 Adria-Wien Pipeline and Wietersdorfer \& Peggauer Zementwerke C-143/99 ECLI:EU:C:2001:598.

19 E.g. Judgement 6 September 2006, Portugal v Commission C-88/O3 ECLI:EU:C:2006:511, para 56. 
can be measured and identified. ${ }^{20}$ The assessment shall not be arbitrary, but it shall take into consideration essential joint features and differences according to the respective context. ${ }^{\mathbf{2 1}}$

Assessing whether a derogation exists is the key element of this part of the test and allows a conclusion to be drawn as to whether the measure is prima facie selective. If the measure in question does not constitute a derogation from the reference framework, it is not selective. However, if it does (and therefore is prima facie selective), it needs to be established, in the third step of the test, whether the derogation is justified by the nature or the general scheme of the (reference) system. ${ }^{22}$ The three-stage approach has been a useful assessment tool in several fiscal aid cases. ${ }^{\mathbf{2 3}}$ As said before, this analysis does not cover the analysis of the justification but only discusses the problematics related to the first two stages of the three-stage analysis.

The ECJ has stated in the Portugal $v$ Commission judgement that the determination of the reference framework has a particular importance in the case of tax measures, since the very existence of an advantage may be established only when compared with 'normal' taxation. ${ }^{\mathbf{2 4}}$ This comparison requires not only familiarity with the content of the provisions of relevant law but one also has to understand the nature of the national tax regime under scrutiny. The reference framework is composed of a consistent set of rules that generally apply - on the basis of objective criteria - to all undertakings falling within its scope as defined by its objective. In the case of taxes, the reference framework is based on such elements as the tax base, the taxable persons, the taxable event and the tax rates. ${ }^{25}$ When assessing the selectivity of a tax reduction or a tax exemption the reference framework is fairly easy to define. In the first case, it is the rate from which the reduction is derived and in the latter case, it is the tax from which the exemption is drawn. ${ }^{\mathbf{2 6}}$ Normally, the comparison is made between a derogation and a principle rule. However, there might be divergent views on what is the applicable principle rule. The ECJ

20 Schön (2016), p.7.

21 Michael Lang State Aid and Taxation: Selectivity and Comparability Analysis. In: Richelle I., Schön W. Traversa E. (eds) State Aid Law and Business Taxation. MPI Studies in Tax Law and Public Finance, vol 6. Springer, Berlin, Heidelberg 2016 (Lang 2016), p. 36.

22 See e.g. Judgement 19 December 2018, A-Brauerei C- 374/17, ECLI:EU:C:2018:1024, para 44 and Judgement 21 December 2016, Commission v World Duty Free Group and Others Joined Cases C-20/15 $P$ and C-21/15 P, ECLI:EU:C:2016:981, para 58

23 See e.g. Judgement 19 December 2018, A-Brauerei C- 374/17, ECLI:EU:C:2018:1024, Judgement 28 June 2018, Andres (faillite Heitkamp BauHolding) $v$ Commission C-203/16 P, Judgement 15 November 2011, Commission and Spain v Government of Gibraltar and United Kingdom Joined Cases C-106/09 P and C-107/O9 P, ECLI:EU:C:2011:732, Judgement 8 September 2011, Paint Graphos and Others Joined Cases C-78-80/08, ECLI.EU.C.2011:550 and Judgement 8 November 2001 Adria-Wien Pipeline and Cases C-78-80/ (143/99 ECLI:EU:C:2001:598.

24 Judgement 6 September 2006, Portugal v Commission C-88/O3 ECLI:EU:C:2006:511, para 56

25 See more about the general guidelines on identification of the reference system the Commission Notice on the notion of State aid as referred to in Article 107(1) of the Treaty on the Functioning of the European Union, OJ 2016 C 262, paras 132-134

26 Phedon Nicolaides, The Definition of the Reference Tax System Is Still a Puzzle, European State Aid Law Quarterly 2018 (Nicolaides 2018), p.423. has taken steps towards further guidance on this conundrum. As a general rule regarding tax advantages, the ECJ has recently concluded the following:

"With regard to a national measure conferring a tax advantage of general application, the condition relating to selectivity is satisfied where the Commission is able to demonstrate that that measure is a derogation from the ordinary or 'normal' tax system applicable in the Member State concerned, thereby introducing, through its actual effects, differences in the treatment of operators, although the operators who qualify for the tax advantage and those who do not are, in the light of the objective pursued by that Member State's tax system, in a comparable factual and legal situation." ${ }^{27}$

There are three elements to stress in this rule: (1) the determination of the ordinary or 'normal' tax system, (2) the investigation of actual effects and (3) the concept of comparable factual and legal situation.

It is not yet clear and simple how the abovementioned rule applies in all circumstances. The definition of selectivity itself is still open to various interpretations despite the fact that the ECJ has examined selectivity issues in several cases in the 2000s. The Gibraltar case was the first in which the ECJ explicitly concluded that a whole fiscal system was intrinsically selective. ${ }^{\mathbf{2 8}} \mathrm{As}$ discussed below, the judgement has significantly broadened the interpretation of the selectivity condition and the application of Article 107(1) TFEU. ${ }^{29}$

\section{GIBRALTAR CASE - JOINED CASES C-106/09 P AND C.I07/09 P, COMMISSION AND SPAIN V GOVERNMENT OF GIBRALTAR AND UNITED KINGDOM}

Defining the relevant reference framework is somewhat simple in cases where the tax advantage is based on a derogation from a general rule. The Gibraltar case was a bit more complex. In this case a tax (or rather non-taxation) result was achieved by adjusting and combining the tax rules in such a way that their application resulted in a different tax burden for different undertakings. In the judgement given in 2011, the ECJ finally held that the whole Gibraltar tax reform was materially selective since it conferred selective advantages on offshore companies.

27 Judgement 25 July 2018, Commission v Spain and Others C-128/16 P, ECLI:EU:C:2018:591, para 69 and Judgement 21 December 2016, Commission v World Duty Free Group and Others Joined Cases C-2O/15 P and C-21/15 P, ECLI:EU:C:2016:981, para 67.

28 Piernas Lopez, Juan Jorge, The Concept of State Aid Under EU Law. Oxford: Oxford University Press 2015. Piernas Lopez (2015), p.150.

29 See e.g. Maarten Aalbers, Gibraltar: A Rock Solid Interpretation of the Selectivity Criterion. European State Aid Law Quarterly 2017. Aalbers (2017). 
In 2002, the Government of Gibraltar introduced an entirely new corporate tax regime for all companies in Gibraltar which departed from the conventional profit-based corporate tax. The new system included three different taxes: (1) a payroll tax the amount of which depended on the number of employees (2) a business property occupation tax ("BPOT"), and (3) a relatively small registration fee which was GBP 300 per annum in the case of companies intended to generate income. ${ }^{30}$ The ECJ held that the new tax regime in fact excluded from the outset any taxation of offshore companies since they have no employees and also do not occupy business property. ${ }^{\mathbf{3 1}}$

The General Court had criticized the Commission for failing to identify a relevant reference framework. The ECJ, however, held that the Commission had examined the existence of selective advantages for offshore companies in the light of the tax regime at the issue, which formally applies to all undertakings. The ECJ held that the Commission had correctly established that the corporate tax law system was considered to be the national reference framework. ${ }^{32}$ AG Jääskinen had regarded that, in his view, to accept the Commission's approach would lead to 'a methodological revolution in the application of the rules relating to State aid for the purposes of Article 87(1) EC [now Article 107(1) TFEU], ${ }^{33}$ One could say that the ECJ purposefully adopted by this judgement a transition towards a new less formalistic approach and stressed the substance of the tax regime under scrutiny.

The ECJ regarded that the General Court had erred in law in finding that the proposed tax reform did not confer selective advantages. The ECJ held that the approach which was based on the regulatory technique used by the proposed tax reform did not take into account the effects of the

30 As to the background of the case, the European Commission had opened a State aid formal investigation procedure in Gibraltar in 2001 and a year later, Gibraltar notified to the Commission this entirely new corporate tax regime. The new proposed tax reform was based on the features listed above. According to the proposed tax reform 'all Gibraltar companies will be liable to a payroll tax in the amount of GBP 3000 per employee each year; every 'employer' in Gibraltar will be required to pay payroll tax in respect of the total number of its full-time and part-time 'employees' who are 'employed in Gibraltar' and 'all companies occupying property in Gibraltar for business purposes will have to pay a tax on the occupation of that property at a rate equivalent to a percentage of their liability to the general rates charged on property in Gibraltar'.

31 Judgement 15 November 2011, Commission and Spain v Government of Gibraltar and United Kingdom Joined Cases C-106/09 P and C-107/09 P, ECLI:EU:C:2011:732, para 102

32 ibid para 95

33 Commission and Spain v Government of Gibraltar and United Kingdom, Opinion of AG Jääskinen, para 202 tax measure in question and was thus at variance with the EU case law. ${ }^{\mathbf{3 4}}$ Secondly, this approach disregarded the settled case law, according to which the existence of a selective advantage for an undertaking entails mitigation of the charges which are normally included in its budget. ${ }^{\mathbf{3 5}}$

In this judgement, the ECJ finally adopted an effects-based and more substance-oriented approach to determining the relevant reference framework. The ECJ underlined that in this case the regime at issue was to be examined as a whole. The ECJ held that even though the criteria of the payroll tax and the BPOT were of general nature they factually lead to a situation where the offshore companies were not taxed. In other words, the non-taxation of offshore companies in these circumstances was foreseeable. The ECJ regarded that the fact that offshore companies were not taxed was not a random consequence of the regime at issue, but 'the inevitable consequence' of the fact that the bases of assessment were specifically designed so that offshore companies, which by their nature have no employees and do not occupy business premises, had no tax base under the bases of assessment adopted in the proposed tax reform. ${ }^{36}$

The Gibraltar case confirms that the EU State aid regulation cannot be bent by giving a group of companies tax advantages which are of general nature but factually based on the specific features characteristic of that group. The ruling was that the advantages accruing to offshore companies were considered a prohibited State aid. The relevant reference framework was not a single rule but the national corporate tax law system.

The ECJ had already stated in the British Aggregates judgement that Article 107(1) TFEU defines State interventions on the basis of their effects, and thus independently of the techniques used. ${ }^{37}$ In the Gibraltar case, the de facto selectivity resulted, however, from a regulatory technique which was of a general nature and thus the ECJ had to develop a new, less formal and more substance-oriented doctrine.

34 Judgement 15 November 2011, Commission and Spain v Government of Gibraltar and United Kingdom Joined Cases C-106/09 P and C-107/09 P, ECLI:EU:C:2011:732, paras 87-88. The ECJ referred to Judgement 22 December 2008, British Aggregates v Commission C-487/06 P, ECLI:EU:C:2008:757, paras 85 and 89 and Judgement 8 September 2011, Commission v Netherlands C-279/08 P, ECLI:EU:C:2011:551, para 51.

35 Judgement 15 November 2011, Commission and Spain v Government of Gibraltar and United Kingdom Joined Cases C-106/09 P and C-107/O9 P. ECLI:EU.C.2011:732, para 89

36 ibid paras 89 and 106

37 Judgement 22 December 2008, British Aggregates v Commission C-487/06 P. ECLI:EU:C:2008:757, para 89. 


\section{IMPACT OF THE GIBRALTAR JUDGEMENT ON POST CASE LAW - C.203/ I 6 P, HEITKAMP BAUHOLDING V COMMISSION}

A more recent judgement, Heitkamp BauHolding ${ }^{\mathbf{3 8}}$, concerned the German 'Sanierungsklausel', a restructuring clause in the German tax system which aimed at helping companies in financial difficulties by allowing them to carry forward losses despite changes in their shareholdings. ${ }^{39}$ This judgement shows that there can be divergent views on what is the relevant reference framework even in cases where, on the face of it, the answer seems quite obvious. The ECJ found that the Commission and the General Court had both determined the reference framework incorrectly and thus annulled the Commission decision.

According to the general loss carry-forward rule of the German income tax act ('Einkommensteuergesetz'), losses made in the course of a tax year may be carried forward to later tax years, with the result that the losses in question may be subtracted from the taxable income of the following years. In principle, the rule governing the forfeiture of losses of the German corporation tax act ('Körperschaftsteuergesetz, KStG') limited or excluded the possibility of carrying forward losses if there were certain kind of changes in a company's shareholdings ('the prejudicial acquisition of a shareholding'). Pursuant to the Paragraph 8c(1) of the KStG, if, within a period of five years, $25 \%$ to $50 \%$ of the subscribed share capital, membership rights, ownership rights or voting rights is transferred, unused losses are forfeited on a pro rata basis. Moreover, unused losses are forfeited if more than $50 \%$ of the share capital, membership rights, ownership rights or voting rights is transferred to an acquirer.

The disputed measure in this case concerned an exemption provision which aimed at helping companies having financial difficulties. Pursuant to the Subparagraph 1a ('the restructuring clause'), an entity may carry losses forward, even in the event of a prejudicial acquisition of a shareholding within the meaning of Paragraph $8 \mathrm{c}(1)$ of the KStG, provided that: (i) the acquisition serves the purpose of restructuring the corporate entity, (ii) the company is, or is likely to be, insolvent or over-indebted at the time of the acquisition, (iii) the company's fundamental business structures are preserved, which essentially entails the safeguarding of jobs, a significant injection of business assets, or write-off of debts which are still recoverable, (iv) the company does not change its sector of activity during the five years following the acquisition, and (v) the company had not ceased operation at the time of the acquisition.

38 Judgement 28 June 2018, Andres (faillite Heitkamp BauHolding) v Commission C-203/16 P, EU:C:2018:505.

39 On 28 June 2018, the ECJ also gave three other judgements dealing with the same tax measure: Judgement 28 June 2018, Lowell Financial Services v Commission C-219/16 P, ECLI:EU:C:2018:508, Judgement 28 June 2018, Germany v Commission C-209/16 P, ECLI:EU:C:2018:507 and Judgement 28 June 2018, Germany v Commission C-208/16 P, ECLI:EU:C:2018:506.
In this case, the ECJ examined a situation in which two sets of rules seemed capable of constituting the relevant reference framework: (1) the general loss carry-forward rule and (2) the rule governing the forfeiture of losses. Both the Commission and the General Court had defined the relevant reference framework covering the rule governing the forfeiture of losses, but the ECJ deviated from this view and stated that they both had erred in law.

The ECJ underlined again the important principle that form of State intervention cannot prevail over its effect. The ECJ held that the classification of a tax system as 'selective' is not conditional upon that system being designed in such a way that undertakings which might enjoy a selective advantage are, in general, subject to the same tax burden as other undertakings but benefit from derogating provisions. ${ }^{40}$ The formal objectives of a tax measure are not decisive, but the effects of the measure. An interpretation which would rely the comparison of tax rules solely on the regulatory technique would lead to a situation where national tax rules would fall from the outset outside the scope of control of State aid. Thus, the ECJ stated clearly that the regulatory technique used cannot be decisive for the purposes of the determination of the reference framework. ${ }^{41}$

The main point of the judgement is that the ECJ held that the General Court had defined the relevant reference framework manifestly too narrowly. The ECJ held that the restructuring clause's effect was to define a situation falling under the general loss carry-forward rule, not the rule governing the forfeiture of losses. ${ }^{42}$ The rule governing the forfeiture of losses was itself an exemption to the loss carry-forward rule.

The ECJ also held that the selectivity of a tax measure cannot be precisely assessed on the basis of a reference framework consisting of some provisions that have been artificially taken from a broader legislative framework. ${ }^{\mathbf{4 3}}$ However, the ECJ did not define explicitly what it meant by stating that the General Court had 'artificially' brought the Sanierungsklause/ under an incorrect reference framework. Nicolaides has brought up a view that ECJ might have intended to say that companies which are in the same position as other companies in relation to reference system $A$ should not be artificially brought under a different reference system $B .{ }^{44}$ It must be borne in mind that in this case the General Court had found that there was a general tax rule applicable to all undertakings subject to corporation tax, the loss carry-forward rule. ${ }^{45}$

40 Judgement 28 June 2018, Andres (faillite Heitkamp BauHolding) v Commission C-203/16 P, EU:C:2018:505, para 90 and Judgement 15 November 2011, Commission and Spain v Government of Gibraltar and United Kingdom Joined Cases C-106/O9 P and C-107/O9 P, ECLI:EU:C:2011:732, para 91 41 Judgement 28 June 2018, Andres (faillite Heitkamp BauHolding) v Commission C-203/16 P, EU:C:2018:505, paras 92 and 104

42 ibid paras 102-103.

43 ibid para 103.

44 Nicolaides (2018), p. 423

45 Judgement of 4 February 2016, Heitkamp BauHolding v Commission T-287/11, ECLI:EU:T:2016:60, para 105 
However, it took the view that the relevant reference framework was constituted only by the rule governing the forfeiture of losses. The ECJ held that the General Court had disregarded the overall examination of the content of those provisions. ${ }^{\mathbf{4 6}}$ Perhaps what the ECJ meant by this artificial measure was to emphasize that both the content and the effects of the tax provisions must be examined carefully. As I see it, the ECJ focused on the examination of the scope of the German tax system. The Sanierungsklause/ was a general measure which aimed at helping companies having financial difficulties and thus the comparison between the Sanierungsklausel and the exemption rule governing the forfeiture of losses was not functional.

According to Nicolaides, the resolution of the conundrum of deciding the correct reference framework comes down to matching companies with the relevant tax rules. ${ }^{47}$ The ECJ held that companies in financial difficulties were in the set of all companies carrying losses forward. The General Court had held that the tax measure's main objective to facilitate the restructuring of undertakings in difficulty did not come within the founding or guiding principles of the tax system and was therefore not intrinsic, but extrinsic thereto. ${ }^{48}$ The ECJ did not take a stand on this issue but reminded that Article 107(1) TFEU does not distinguish between measures of State intervention by reference to their causes or their aims but defines them in relation to their effects. ${ }^{49}$ As I see it, the ECJ's ruling is in line with the settled case law and a different interpretation would have raised even more open questions.

The Heitkamp BauHolding judgement shows that the ECJ has irretrievably deviated from the formalistic approach and that the selectivity assessment is always primarily effects-based and substance-oriented. In order to determine whether a national tax measure deviates from the reference framework, only its effects are taken into account and not the regulatory technique used by a Member State.

46 Judgement 28 June 2018, Andres (faillite Heitkamp BauHolding) v Commission C-203/16 P, EU:C:2018:505, para 102

47 Nicolaides (2018), p. 427

48 Judgement of 4 February 2016, Heitkamp BauHolding v Commission T-287/11, ECLI:EU:T:2016:60, para 166.

49 Judgement 28 June 2018, Andres (faillite Heitkamp BauHolding) v Commission C-203/16 P, EU:C:2018:505, para 91

\section{CONCLUSIONS}

While usually the selectivity analysis is based on finding the relevant general rules applying to all undertakings from which a derogation is made for certain undertakings, the Gibraltar analysis needed a more developed doctrine. In the Gibraltar judgement, the selective result was achieved not through a derogation from the normal tax regime, but through the application of that regime. The statement of the Gibraltar judgement is that a tax measure may be selective not only in the form of an exemption rule but also when it factually and intentionally defines a scope which gives tax advantages for a certain group of undertakings. The wording of the ECJ is an 'inevitable consequence'. In this judgement, the ECJ deviated from its formalistic approach and adopted the effect-based approach which stresses the substance of a tax regime. The Gibraltar case shows that in complex fiscal cases it is necessary to consider carefully the effects of the tax provisions as a whole. The judgement has materially broadened the interpretation of the selectivity condition and the application of Article 107(1) TFEU.

The Heitkamp BauHolding judgement confirms the Gibraltar judgement and stresses that the legal wording and the regulatory technique are not decisive in the assessment of whether a tax measure deviates from the general rule. The intention and the scope of the tax regime as a whole form the core issue under scrutiny. This doctrine may be helpful in cases where more than one set of tax rules could apply but it still leaves some questions open, such the artificial element brought up in the judgement. Nevertheless, it is crystal clear that the selectivity assessment is nowadays always primarily effects-based.

As Sierra has stated, selectivity cannot be an all-embracing concept but must have limits: "After all, a legal concept without limits is not a legal concept" ${ }^{\mathbf{5 0}}$ Despite the recent developments in the selectivity doctrine a more detailed doctrine would be desired. Even though the concept of selectivity is challenging to tie down in tax matters the ECJ has concluded some general rules. Yet the offset of the selectivity assessment i.e. the determination of the relevant reference system is still receptive to various interpretations. It is left to the ECJ to further clarify the limits of this new interpretation.

50 Sierra (2018), p.86. 